\title{
Communication
}

[Comunicação]

\section{Uveitis due to anaplasmosis in a newborn Holstein calf}

[Uveite por anaplasmose em bezerro da raça Holandesa]

\author{
J.L. Laus $^{1}$, J.P.D. Ortiz $^{2}$, F.A.M. Vicenti ${ }^{2}$, F.L.C. Brito ${ }^{2}$, L.M. Wehrle ${ }^{3}$, A. Castro Netto ${ }^{3}$, C.B.S. Lisbão ${ }^{4}$ \\ ${ }^{1}$ Faculdade de Ciências Agrárias e Veterinárias - UNESP \\ Via de Acesso Prof. Paulo Donato Castellane, s/n \\ 14884-900 - Jaboticabal, SP \\ ${ }^{2}$ Aluno de pós-graduação - UNESP - Jaboticabal, SP \\ ${ }^{3}$ Residente - UNESP - Jaboticabal, SP \\ ${ }^{4}$ Médica Veterinária Autônoma
}

Uveitis is defined as an inflammation of the uveal tract, and it is a common manifestation of most intra-ocular diseases. The vascular nature and proximity of the uveal tract to other ocular structures make it vulnerable to inflammatory processes. Uveitis is characterized by many ocular signs and may be originated from either exogenous or endogenous stimuli (Slatter, 1990).

Anterior uveitis clinical signs include epiphora, conjunctival erythema, reduced intra-ocular pressure, corneal edema, miosis and ocular discomfort, among others (Gelatt, 1999). It is presented as a bilateral entity when occurring as a consequence of a systemic disease (Slatter, 1990), which it is commonly associated (Whitaker et al., 1998). Among the most common diseases in bovine are neonatal infections, bacterial septicemia associated to severe mastitis, malignant catarrhal fever and tuberculosis (Rebhun, 1984; Watson, 1994).

Anaplasmosis is a contagious infectious disease caused by a ricketsia from the Anaplasmataceae family, which is mainly represented by the Anaplasma marginale species (Zaugg et al., 1984). It is presented as an acute manifestation, with hemolytic and febrile characteristics, especially in bovines (Corrêa and Corrêa, 1992). It causes high mortality rates (Magonigle, 1975) and important economic losses, especially in

Recebido em 10 de setembro de 2004

Aceito em 21 de agosto de 2006

E-mail: jllaus@fcav.unesp.br tropical and subtropical regions (Eriks et al., 1993).

The transmission of this agent has been a controversy issue, even though experimental data indicate that ticks from the Boophilus microplus species are the main biological vector in Brazil (Stiller and Coan, 1995). Other less important transmission ways are the iatrogenic (Abdalla et al., 1998) and contact with contaminated fomites or hematophagous dipteran insects (Barbet, 1995). Results obtained by Norton et al. (1983), Potgieter and Van Rensburg (1987) indicated the occurrence of trans-placental or intra-uterine transmission from chronically infected cows. However, such condition is infrequent and responsible for less than $1 \%$ of the clinical cases in animals younger than 6-months-old (Ribeiro and Reis, 1981).

After the infection by $A$. marginale, there is an incubation period of about 30 days (Stuart, 1993). The clinical signs include depression, anorexia, fever and icterus in severe cases (Fraser, 1991). These signs are less remarkable in patients younger than 6-months-old (Corrêa, 1978; Stuart, 1993). There are no reports of ocular manifestations of anaplasmosis in bovine.

It is reported a case of a newborn calf with a history of fever, apathy, anorexia and ocular discomfort. A complete ophthalmic examination was performed. The Schirmer tear test values 
were increased, the applanation tonometry ${ }^{1}$ revealed lowered intra-ocular pressure, and the biomicroscopic ${ }^{2}$ examination evidenced bilateral conjunctival congestion and hemorrhage, anterior uveitis, corneal edema and ciliary injection with corneal vessels extending onto 2 to $3 \mathrm{~mm}$ (Fig. 1 and 2).

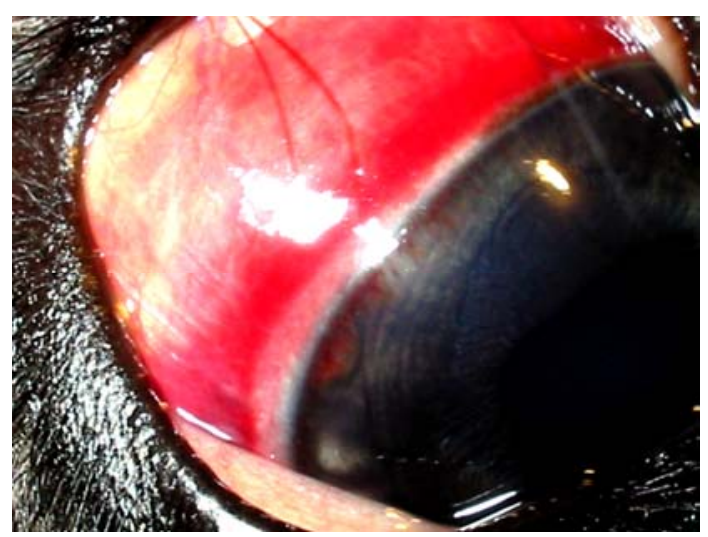

Figure 1. Photographic image of the calf's right eye, presenting conjunctival congestion and hemorrhage, ciliary injection and corneal vascularization. Animal was proved infected by A. marginale.

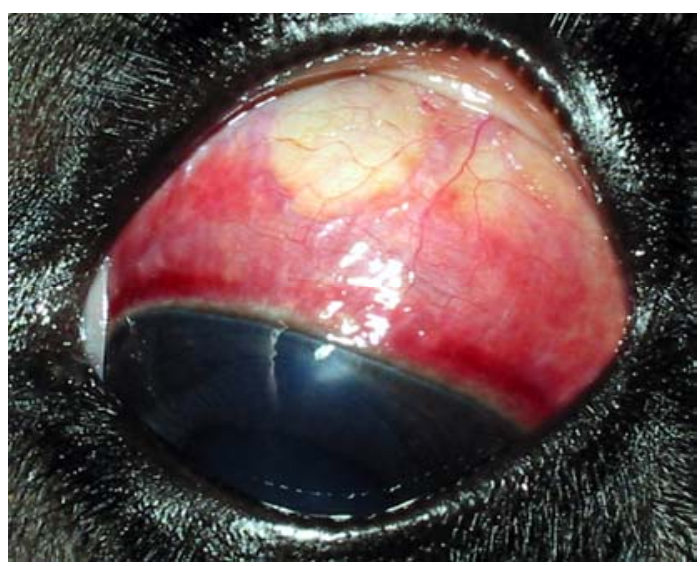

Figure 2. Photographic image of the calf's left eye, presenting conjunctival congestion and hemorrhage, ciliary injection and corneal vascularization. Animal proved infected by $A$. marginale.

Blood samples were collected for blood smear, complete blood cell count and serum biochemistry. A. marginale corpuscles were

\footnotetext{
${ }^{1}$ Tono pen XL - Mentor Medical

${ }^{2}$ Slit Lamp SL-14 - Kowa Company Ltd.
}

encountered in parasited red cells (Fig. 3). The serum biochemistry values were within the normal ranges.

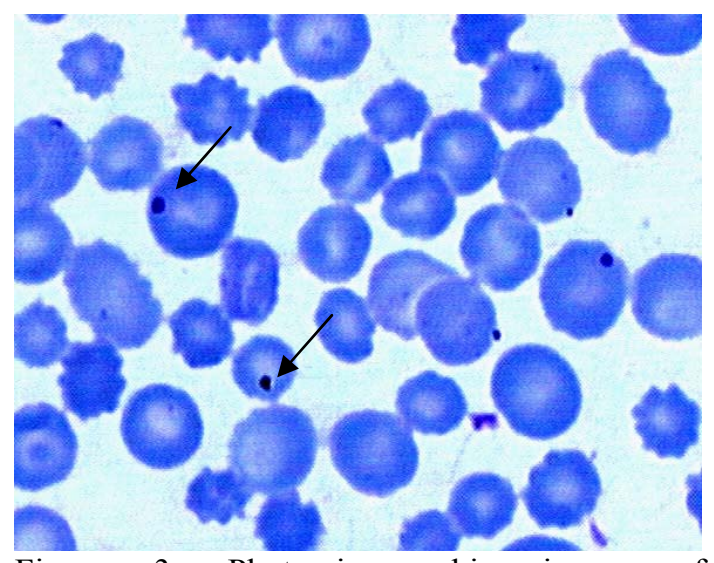

Figure 3. Photomicrographic image of Anaplasma marginale corpuscles (arrows) which were encountered in parasited red cells.140X.

Uveitis was controlled by an unique subconjunctivally application of $0.5 \mathrm{ml}$ of $5 \%$ betamethasone on each eye. Anaplasmosis infection was treated with oxytetracycline ${ }^{3}$ $(10 \mathrm{mg} / \mathrm{kg})$ via deep intramuscular injection, each 12 hours, for 3 days.

Once bilateral uveitis was diagnosed, it was suspected as being secondary to a systemic disease (Slatter, 1990). Considering the ciliary injection invading 2 to $3 \mathrm{~mm}$ on the cornea, it was admitted that the disease had initiated before birth.

Deep corneal vascularization may indicate chronic lesion (Slatter, 1990). According to Stades (1998), the corneal vessels are formed in a rate of approximately $1 \mathrm{~mm}$ per day.

Anaplasmosis infection was diagnosed by parasitological methods (Corrêa, et al. 1978). The examination allowed the detection of $A$. marginale corpuscles in parasited red cells in the first week of the patient's life, according to Norton et al. (1983) and Potgieter and Van Rensburg (1987), who reported that the transplacental transmission is rare, but possible.

Other causes of uveal tract disease in bovine, as newborn infections and bacterial septicemia

${ }^{-3}$ Oxitetraclicina LA (Bayer S.A.). 
(Rebhum, 1984; Watson, 1994), were considered as differential diagnosis but were not concluded as being relevant in this case.

The clinical signs presented by infected calves younger than 1 year-old may be mild (Stuart, 1993) or even absent (Ribeiro and Reis, 1981). In the case reported, the systemic alterations were mild.

A. marginale is highly sensible to tetracyclines, hence the use of this drug allowed the abolishment of clinical signs after three days of treatment, as reported by Magonigle (1975). Ocular signs gradually disappeared within five days after the antiinflammatory injection.

A. marginale may promote uveitis in bovine fetus, transplacentally infected.

Keyword: bovine, Holstein, uveitis, anaplasmosis

\section{RESUMO}

Relata-se o caso de um bovino com, aproximadamente, seis horas de vida, apresentando histórico de febre, apatia, inapetência e desconforto ocular. No exame oftálmico rotineiro, encontraram-se valores do teste da lágrima de Schirmer aumentados, diminuição da pressão intra-ocular, hemorragia conjuntival, uveite anterior, edema corneal e injeção ciliar em ambos os olhos. Coletou-se amostra de sangue para realização de esfregaço sangüineo, hemograma e bioquímica sérica. No esfregaço visibilizaram-se corpúsculos de Anaplasma marginale em hemácias parasitadas. Quanto à bioquímica sérica, não foram observadas alterações. Os mesmos exames foram realizados na mãe do animal tendo como resultado a positividade para A. marginale. Para o controle da uveíte foi utilizada uma única aplicação de 0,5ml de betametasona a 5\%, por via subconjuntival, em cada um dos olhos. Para o tratamento da anaplasmose, seguiu-se o protocolo a base de $10 \mathrm{mg} / \mathrm{kg}$ de oxitetraciclina, por via intramuscular profunda, a cada 12 horas. Diante os achados oftálmicos e a presença de corpúsculos de A. marginale em hemácias parasitadas, contatou-se, ser um caso de uveíte crônica secundaria a doença sistêmica, factível com Anaplasmose.

Palavras-chave: bovino, Holandês, uveite, anaplasmose

\section{REFERENCES}

ABDALLA A.A.; MANGOLD A.J.; TORIONI S. Control y erradicación de la anaplasmosis en un rodeo lechero. Vet. Argent., v.15, p.341-346. 1998.

BARBET, A.F. Recent developments in the molecular biology of anaplasmosis. Vet. Parasitol., v.57, p.43-49, 1995.

COLLINS, B.K.; MOORE, C.P. Doenças e cirurgia da úvea anterior do cão. In: GELATT, K.N. Manual de oftalmologia veterinária. Barueri: Manole, 2003. p.594.

CORRÊA, W.M. Bovine abortion associated whit anaplasma marginale. Can. J. Comp. Med., v.42. p.227-229, 1978.
CORRÊA, W.M.; CORRÊA, C.N.M. Enfermedades infecciosas dos mamiferos domésticos. Rio de Janeiro: Médica e Científica, 1992. p.469.

ERIKS, L.S.; STILLER, D.; PALMER, G.H. Impact of persistent Anaplasma marginale rickettsemia on tick infection and transmission. J. Clin. Microbiol., v.31, p.2091-2096, 1993.

FRASER, C. L. Manual Merk de veterinária. 7.ed. São Paulo: Roca, 1991.

GELLAT, K.N. Veterinary ophthalmology. Pensylvania: Lippincoutt Williams \& Wilkins, 1999. p.392.

MAGONIGLE, R.A. Effect of five, daily intravenous treatments with oxytetracycline hydrocloride on the carrier status of bovine anaplamosis. J. Am. Vet. Med. Assoc., v.167, p.1080-1083, 1975. 
NORTON, J.H.; PARKER, R.J.; FORBESFAULKNER, J.C. Neonatal anaplasmosis in a calf. Am. Vet. J., v.60, p.348, 1983.

POTGIETER, F.T.; VAN RENSBURG, L. The persistence of colostral Anaplasma antibodies and incidence of in utero transmission of Anaplasma infections in calves under laboratory conditions. J. Vet. Res., v.54, p.557-560, 1987.

REBHUM, W.C. Ocular manifestations of sistemic diseases in cattle. Vet. Clin. North. Am: Large. Anim. Pract., v.6, p.623-639, 1984.

RIBEIRO, M.F.B.; REIS, R. Prevalência da anaplasmose em quatro regiões do Estado de Minas Gerais. Arq. Esc. Vet., UFMG, v.33, p.5762, 1981.

SLATTER, D. Fundamentals of veterinary ophtalmology. 2.ed. Philadelphia: Saunder, 1990. p.304-307.

STADES, F.C.; BOEVÉ, M.H.; NEUMANN, W. et al. Ophthalmology for the Veterinary Practioner. Hannover: Schlütersche $\mathrm{GmbH}$ \& Co. KG, 1998. p.117-1127.
STILLER, D.; COAN M.E. Recent developments in elucidating tick vector relationship for anaplasmosis and equine piroplasmosis. Vet. Parasitol., v.57, p.97-108. 1995.

STUART, D.L. Causas infecciosas de anemia hemolitica. Anaplasmose. In: Tratado de medicina interna de grandes animais. São Paulo: Manole, 1993. cap.31. p.1078-1080.

WATSON, C. L. Bovine iritis. In: WORLD BUIATRICS CONGRESS, 18.; CONGRESS OF THE ITALIAN ASSOCIATION OF BUIATRICS, 26., 1994, Bologna. Proceedings... Bologna: Societa Italiana di Buiatria, 1994. v.1, p.495-498.

WHITAKER, J.G.; GELATT, K.N.; WILKIE, D.A. Food animal ophthalmology. In: Veterinary ophthalmology. 3.ed. Philadelphia: Lippincott Williams \& Wilkins, 1998. p.1117-1176.

ZAUGG J.L.; KUTTLER K.L. Bovine anaplasmosis: in utero transmission and the immunologic significance of ingested colostral antibodies. Am. J. Vet. Res., v.45. p.440-443, 1984. 